\title{
Analysis of Student Errors in Constructing Holistic Rubric Based on SOLO Taxonomy
}

\author{
Rosita Dwi Ferdiani ${ }^{1}$, Nur Farida ${ }^{2}$ \\ Department of Mathematics Education \\ Kanjuruhan University \\ Malang, Indonesia \\ ${ }^{1}$ Rositazahra22@gmail.com \\ ${ }^{2}$ Faridanaufal22@gmail.com
}

\begin{abstract}
The aim of this research is to analyze student errors in constructing a holistic rubric based on SOLO taxonomy. This research employs qualitative research methodology. The subject of this research is students of mathematics education program. The consideration in selecting the subject is based on the students' score that belongs to each quartile: quartile 1 , quartile 2 , and quartile 3. Therefore, there are three subjects participating in this research. The researcher analyzed student errors in constructing holistic rubric based on SOLO taxonomy. Based on the data finding, it could be concluded that subject 1 is at the relational level in preparing mathematical problem and at the level of unistructural in constructing rubric. Then, subject 2 is at the multistructural level in composing mathematical problem and is at the relational level in constructing the rubric. Next, subject 3 is at the multistructural level in composing mathematical problem and is at the relational level in constructing the rubric. Based on the analysis of student errors in preparing a holistic rubric based on SOLO taxonomy, it is essential to consider student errors in teaching how to create a holistic rubric, so that students will not make similar error.
\end{abstract}

Keywords-Analysis, error, rubric, holistic

\section{INTRODUCTION}

Assessment is an integral part of learning. It is a mean to evaluate the quality of learning, the achievement of learning goals, and to observe the development of the student's ability. Permendikbud No 66/2013 about the assessment standard stated that the scope of the students learning result assessment includes the attitude competence, knowledge, and skills which are conducted equally so that they can be used to determine the relative position of each student against the assigned standard.

The assessment process for a teacher is not merely giving scores to the students learning result. It is a set of activity contained in the lesson plan, starting from making the questions and their answers, creating the assessment rubric, correcting students answers according to the assessment rubric, adding up the achieved score and converting it into "grade". This grade will measure the students learning result.[1]

A teacher is obliged to be able to conduct the assessment process. An assessment process is not only judging right or wrong, but also observing, analyzing, and making decision about the assessed object.[2] Therefore, a teacher needs to have knowledge in conducting the assessment process. This knowledge is acquired in Mathematics Learning Assessment subject. The achievement in this subject is that the students, as future teachers, can create, organize, and apply the mathematics learning assessment.

Based on the observation on the $4^{\text {th }}$ semester students of Mathematics Education program of Kanjuruhan University Malang in Mathematics Learning Assessment subject, the students made errors in conducting the assessment process, especially when they were constructing holistic rubric. They could not determine the assigned criteria in assessing. These criteria did not match with the problems; hence the problems were not in line with the assessment criteria in the rubric. Almost $60 \%$ of the students could not finish constructing holistic rubric. The rubric itself was an assessment guide which described the assigned criteria in assessing or grading the students work. On the other hand, Holistic Rubric is a rubric that uses single score to assess product, process, and performance. Holistic rubric is more suitable for the performance task which expected the students to give a certain response and there are no absolute correct answer. [1]

Based on the interview with the students participating in the Mathematics Learning Assessment subject, student errors in constructing holistic rubric were because they were not able to make the questions used to assess the product, process, and performance. The students were used to make routine questions about solving mathematical problems or questions about mathematic understanding. These are the factors which cause the students to made errors in determining the criteria in the holisctic rubric.

The tool used to analyze student errors in constructing holistic rubric is SOLO taxonomy. SOLO taxonomy classifies students' ability according to their thinking ability in solving a problem. SOLO taxonomy can be used as an evaluation tool to measure the quality of students' answer for a problem based on the complexity of understanding or the quality of students' answer for a given problem. [3] According to Biggs and Collis, SOLO taxonomy is a tool to evaluate the quality of students' response of a task. This taxonomy consists of five different levels, those are: prastructural, unistructural, multistructural, relational, and extended abstract. [4] The description of the five levels of ability in SOLO taxonomy are: 1) Prastructural level, in this level, the students tend not to give answer. Hence, it can be concluded that the students have not understood the 
given problems. 2) Unistructural level, in this level, the students can solve the problems in a simple and neat way using a piece of information directly from the problems. 3) Multistructural level, in this level, the students can solve the problems accurately, but they cannot relate them using two or more pieces of information from the given problems. 4) Relational level, in this level, the students are able to solve the given problems correctly, and are able to draw a conclusion using two or more pieces of information from the given problems and relate these information. 5) Extended abstract, in this level, the students are able to think inductively and deductively, to use two or more pieces of information from the given problems and relate those information, and then draw a conclusion to construct a new concept and apply it.

Based on the above description, SOLO taxonomy can be used as an evaluation tool to measure the quality of the students' answer, so that the lecturer can find the appropriate solution to minimize student errors in constructing the holistic rubric in Mathematics Learning Assessment subject. Therefore, we are interested to do a research on the analysis of student errors in constructing holistic rubric based on SOLO taxonomy.

\section{RESEARCH METHOD}

This research used natural background in the campus by observing and interviewing the students. The researchers would obtain data naturally from the observation and interview. Thus, we used qualitative approach. According to Denzin and Lincoln (1987) qualitative research is a research which uses natural background, it is meant to interpret phenomena by involving various kinds of natural methods. [5] This research aimed to analyze student errors in constructing holistic rubric based on SOLO taxonomy. Therefore, this research used descriptive research. Descriptive research aims to define a circumstance or phenomenon as it is. [6]

In this research, the researchers acted as the instrument as well as the data collector. The location of this research was in Mathematics Education program of Kanjuruhan University Malang. The data used in this research were students who made errors in constructing holistic rubric based on SOLO taxonomy. According to the data source, the data were divided into two types, i.e.: 1) Primary Data, that is the source who directly gave the data to the researcher. The primary data source in this research was the information from the lecturer of Mathematics Learning Assessment subject and the students work. 2) Secondary Data, that is the data which were directly collected by the researcher from the existing sources, such as documentations, journals, and books.

The subject of this research was three students from class 2014 A. To choose the subject, we used quartile 1 to quartile 3 measurement, so that each quartile would get one student who would make errors in constructing holistic rubric based on SOLO taxonomy. The data of this research were obtained from test result and interview. The instruments used in this research were: 1) Observation Sheet. 2) Test Sheet. 3) Interview
Guidance. The collecting data procedure was done to obtain valid data during the research. In this research, we used two procedures to collect data, those were: test and interview.

\section{RESULT AND DISCUSSION}

Based on the test and interview conducted by the researcher, the student errors found are as follows:

\section{A. Subject 1}

1) Based on the analysis of subject 1's answer when constructing Junior High School mathematics problems about ratio, subject 1 was in relational level. Subject 1 could solve the given problems correctly and could draw a conclusion through thinking and using two or more pieces of information from the given problems and relating them. Subject 1 could construct the problems with clear instruction. The problems were appropriate with the ratio material, but subject 1 could not compose the sentences in Indonesian correctly, so that this could cause double perception.

2) Based on the analysis of subject 1's answer in constructing holistic rubric, subject 1 was in unistructural level. In this level, subject 1 could solve the problems in a simple and neat way using a piece of information clearly and directly from the problems. Subject 1 could construct holistic rubric, but he could not relate the answer to the assessment criteria. The assessment criteria were not clear enough, thus it was difficult to assess. Moreover, the assessment criteria did not show apparent indicators, for example: very able, able, and unable. There were no apparent indicators which indicated that a student was very able, able, or unable.

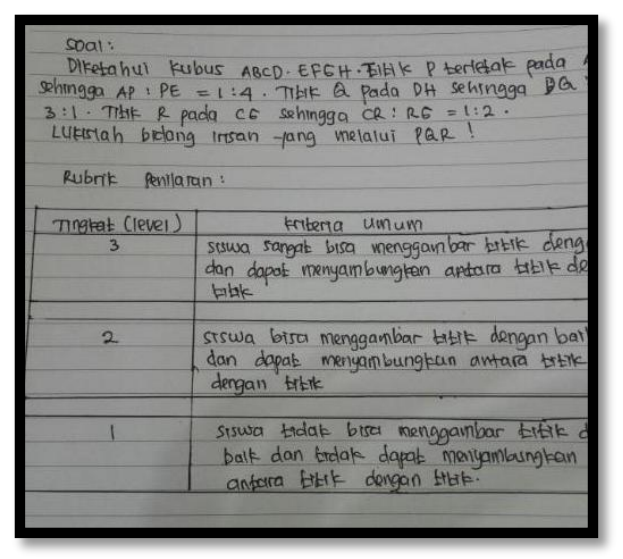

Fig. 1. Answer of subject 1

A. Based on the analysis of subject 2's answer, it was obtained:

1) When constructing Junior High School mathematics problems about Social Arithmethics, subject 2 was in relational level. Subject 2 could solve the given problems correctly and could draw a 
conclusion through thinking and using two or more pieces of information from the given problems and relating them. Subject 2 could construct problems with clear instruction, and there was relation between the problems and social arithmethics material. However, the scope of the problems was too broad, so that it was difficult for the student to find the answer. For example: the instruction asked to find snack products with discounted price. There should have been some limitations about how many items of the products, in order to make it easier for the students to find the answer to the problem.

2)

Based on the analysis of subject 2's answer in constructing holistic rubric, subject 2 was in multistructural level, subject 2 could solve the problems correctly, but could not relate them together using two or more pieces of information from the given problem. The rubric constructed by subject 2 could not mention the assessment indicators clearly. Furthermore, there was no relation between the indicators.
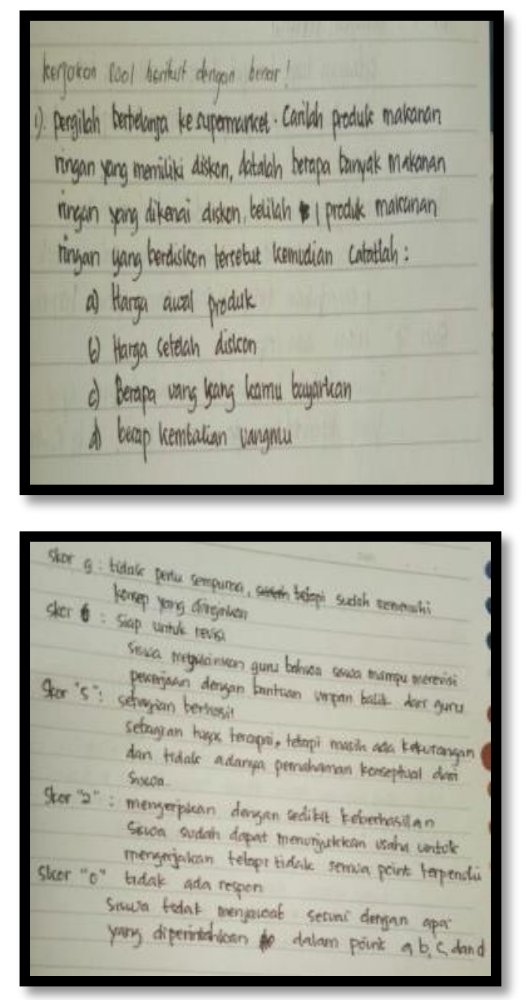

Fig. 2. Answer of subject 2

B. Based on the analysis of subject 3's answer, it was obtained:

1) When constructing Junior High School mathematics problems about Social Arithmethics, subject 3 was in multistructural level. Subject 3 could solve the given problems correctly but could not relate them together by using two or more pieces of information from the given problems. The problems which subject 3 made did not give enough information about the intention of the problems, for example: a carton of egg and a box of Energen.

2) Based on the analysis of subject 3's answer in constructing holistic rubric, subject 3 was in multistructural level. In this level, subject 3 could solve the problems correctly, but could not relate them together using two or more pieces of information from the given problem. The rubric constructed by subject 3 could not mention the assessment indicators clearly. Furthermore, there was no relation between the indicators. For example: the student work met the assigned standard. Subject did not describe the indicator from the teacher standard.
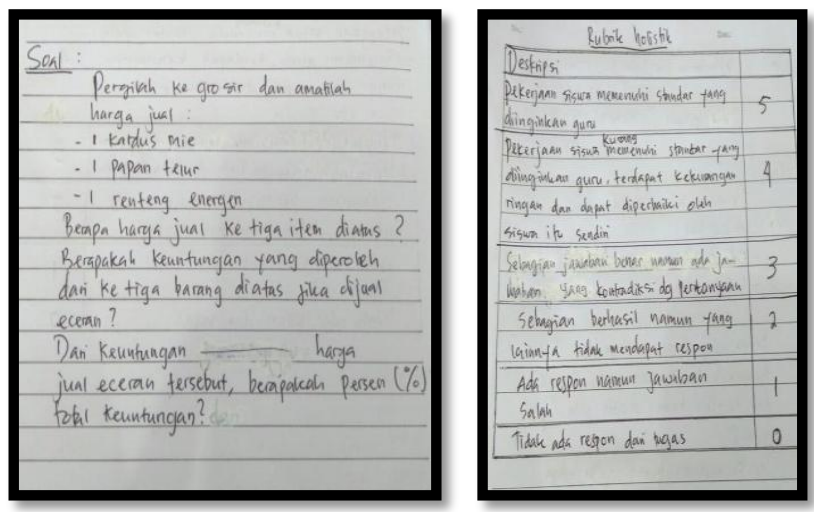

Fig.3. Answer of subject 3

\section{CONCLUSION AND SUGGESTION}

A. Based on the analysis of subject 1 's answer when constructing Junior High School mathematics problems about ratio, subject 1 was in relational level. Based on the analysis of subject 1's answer in constructing holistic rubric, subject 1 was in unistructural level.

$B$. Based on the analysis of subject 2's answer when constructing Junior High School mathematics problems about Social Arithmethics, subject 2 was in relational level. Based on the analysis of subject 2's answer in constructing holistic rubric, subject 2 was in multistructural level.

C. Based on the analysis of subject 3's answer when constructing Junior High School mathematics problems about Social Arithmetic's, subject 3 was in multistructural level. Based on the analysis of subject 3's answer in constructing holistic rubric, subject 3 was in multistructural level. 


\section{Suggestion}

1) In multistructural level, the teacher needs to emphasize on the understanding in constructing holistic rubric by paying more attention to the compatibility of the assigned indicators and the problems. This is needed to prevent the same errors.

2) In relational level, the teacher needs to emphasize on the understanding in constructing holistic rubric by paying more attention to the relation between indicators to make it easier in the assessment.

\section{REFERENCES}

[1] P. Betl. 2008. Mathematics Assessment : A Practical Handbook For Grades 6-8.USA

[2] R. D. Ferdiani, T. R. Murniasih. Pengembangan Instrumen Penilaian Autentik Melalui Tugas Proyek Pada Materi Statistika SMP. Jurnal Inspirasi Pendidikan, Vol.7 no 12017

[3] Kuswana. Wowo S. 2012. Taksonomi Kognitif Perkembangan Ragam Berpikir. Bandung: PT Remaja Rosdakarya.

[4] N.D. Pratiwi, W. Setyarsih. Pengembangan Instrumen Evaluasi Berbasis Taksonomi Structure of the Observed Learning Outcome (SOLO) Untuk Menentukan Profil Kemampuan Siswa dalam Memecahkan Masalah Fluida Statis. Jurnal Inovasi Pendidikan Fisika (JIPF). Vol. 04 No. 03, September 2015, 45-49

[5] Moleong, Lexy J.2013. Metodologi penelitian kualitatif. Bandung: Remaja Rosdakarya.

[6] Sukmadinata, N. 2009. Landasan Psikologi Proses Pendidikan. Bandung: PT Remaja Rosdakarya. 